\title{
On the effects of testosterone on brain behavioral functions
}

\author{
Peter Celec 1,2,3,4 *, Daniela Ostatníková ${ }^{1,5}$ and Július Hodosy ${ }^{1,2,5}$ \\ ${ }^{1}$ Institute of Molecular Biomedicine, Faculty of Medicine, Comenius University, Bratislava, Slovakia \\ ${ }^{2}$ Center for Molecular Medicine, Slovak Academy of Sciences, Bratislava, Slovakia \\ ${ }^{3}$ Institute of Pathophysiology, Faculty of Medicine, Comenius University, Bratislava, Slovakia \\ ${ }^{4}$ Department of Molecular Biology, Faculty of Natural Sciences, Comenius University, Bratislava, Slovakia \\ ${ }^{5}$ Institute of Physiology, Faculty of Medicine, Comenius University, Bratislava, Slovakia
}

\section{Edited by:}

Belinda Pletzer, University of

Salzburg, Austria

Reviewed by:

Henryk Urbanski, Oregon National

Primate Research Center, USA

Justin M. Carré, Nipissing

University, Canada

${ }^{*}$ Correspondence:

Peter Celec, Institute of Molecular

Biomedicine, Comenius University,

Sasinkova 4, 81108 Bratislava,

Slovakia

e-mail:petercelec@gmail.com
Testosterone influences the brain via organizational and activational effects. Numerous relevant studies on rodents and a few on humans focusing on specific behavioral and cognitive parameters have been published. The results are, unfortunately, controversial and puzzling. Dosing, timing, even the application route seem to considerably affect the outcomes. In addition, the methods used for the assessment of psychometric parameters are a bit less than ideal regarding their validity and reproducibility. Metabolism of testosterone contributes to the complexity of its actions. Reduction to dihydrotestosterone by 5-alpha reductase increases the androgen activity; conversion to estradiol by aromatase converts the androgen to estrogen activity. Recently, the non-genomic effects of testosterone on behavior bypassing the nuclear receptors have attracted the interest of researchers. This review tries to summarize the current understanding of the complexity of the effects of testosterone on brain with special focus on their role in the known sex differences.

Keywords: androgen, cognition, emotions, hippocampus, behavioral neuroendocrinology

\section{INTRODUCTION}

Despite current efforts of the European commission to combat gender issues with respect to gender equality, men and women are different in several important aspects (Cahill, 2014). These aspects include cognitive functioning and behavioral traits. Some of these may be socially induced, but scientists have showed on intact animals that other factors such as genetics and gender itself are mostly responsible forthe sex differences in behavior and cognition. Therefore, the current research strategies are calling for including both males and females in the research in order to report the possible gender differences (Ruigrok et al., 2014). Indeed, the exact mechanisms and reasons of sex differences in brain structures that mediate some of these functional dissimilarities are unknown. Genetics and endocrine factors are the most prominent biological explanations and are interconnected. Testosterone is the major male sex hormone. It is present in women, although in much lower concentrations. Testosterone has also been intensively studied in relation to sex differences and behavioral functions. This review focuses on physiology of testosterone to give the reader understanding of the mechanisms and complexity of testosterone action and then tries to summarize the studies and experiments focusing on the functional changes in anxiety, depression, spatial abilities and memory. Readers interested in sex differences and brain structures might find the needed information in the recently published focused review (Filova et al., 2013).

\section{TESTOSTERONE PHYSIOLOGY}

Testosterone is produced mainly in Leydig cells of testes in males, and in ovaries in females. In both, testosterone can be synthetized in the adrenal gland cortex (Burger, 2002; Dohle et al., 2003). However, in addition to the classic steroidogenic organs such as gonads, adrenals and even placenta, the active biosynthesis of steroids also occurs in the brain (Mellon et al., 2001). This synthesis can be either de novo from the cholesterol, or testosterone is derived from classical steroids as is deoxycorticosterone or progesterone, which enter through blood stream into nervous system. The latter one depends on the enzymatic ability of the neural region or cell. The key regulatory enzyme is Steroidogenic acute regulatory protein (StAR) (Miller and Auchus, 2011). This phosphoprotein mediates the transfer of cholesterol from the outer to the inner mitochondrial membrane, from where cholesterol can be further processed by corresponding enzymes. The StAR gene is expressed solely in the steroidogenic tissues. However, StAR mRNA expression in a rat brain was first shown by Furukawa (Furukawa et al., 1998) and confirmed in humans and mouse brains in several regions by immunohistochemistry.

The complexity of testosterone mechanism of action is underlined by its metabolism and steroid nature. The classical view suggests genomic mechanism, i.e., after translocation into cytoplasm, testosterone binds the androgen receptor, and subsequently after transportation into the nucleus it binds on the hormone response element at DNA, where it activates or silences the expression of genes and subsequent protein synthesis (Tsai and O'malley, 1994). During recent years, a new pathway for non-genomic mechanism was shown. This can include activating the membrane receptors and thus activating the second messengers, or after translocation to the cell, testosterone can either directly activate second messenger intracellular cascade, or can bind to its respective receptor and as a complex of hormone-receptor it 
can activate the second messenger cascade (Michels and Hoppe, 2008). Additionally, testosterone can be changed into either estradiol by aromatase or into dihydrotestosterone by reductase. The pathway depends on the enzymatic equipment of the cells.

The synthesis of sex hormones is ultimately controlled by gonadotropin-releasing hormone $(\mathrm{GnRH})$, which is produced by the hypothalamus and which stimulates the pituitary gland to release luteinizing hormone and follicle stimulating hormone, where LH increases the expression of StaR protein in target cells (Ubuka et al., 2014). GnRH secretion in adulthood is pulsatile and highest during sleep with subsequent highest peaks of testosterone to be during the early morning hours (Lord et al., 2014). Nevertheless, the testosterone levels decline gradually with aging, mainly due to the attrition of Leydig cells and hypothalamic GnRH pulse generation slow down. Rapid drop can be observed in the 6th decade of life in males.(Basaria, 2013). A higher incidence of mood disorders that occurs with aging is then related to decreased testosterone and/or other androgens. However, not all studies agree with this simple explanation. Sartorius et al. showed, that there was no decline in testosterone levels in males who selfreported to be in very good health. Indeed, a subgroup of patients who were smoking and/or obese was associated with age related decline in serum androgens (Sartorius et al., 2012). Similarly, Camacho et al. reported that lifestyle factors and body weight were more important in maintaining the plasma testosterone levels than aging itself (Camacho et al., 2013).

In any respect, the causal role of testosterone deficiency and behavioral disorders including effect on cognitive abilities is still debated. Therefore, in the next chapters we will try to summarize the main experimental studies on individual behavioral traits.

\section{ANXIETY}

Our daily decision-making as well as response to stress is our everyday experience. Indeed, many factors contribute and even more factors modify the decision-making and stress reaction, with anxiety level to be one of them. Nevertheless, it has clearly been shown, and recently reviewed that women show higher anxiety in comparison to men (Mchenry et al., 2014). From all behavioral parameters, the anxiety seems to be most sensitive to testosterone. The most cited paper analyzing the effects of testosterone on anxiety in mice has shown in several experiments that testosterone-either endogenous or exogenous decreased anxiety in elevated plus maze (Aikey et al., 2002). In addition, the same study showed that this anxiolytic effect of testosterone is dose-dependent and very likely mediated by 5 -alpha reductase that reduces testosterone to dihydrotestosterone. The study was conducted in male mice, but similar anxiolytic effects of single testosterone administration resulted in reduced fear of healthy women (Van Honk et al., 2005). In rats, a single testosterone injection did not reduce anxiety, however, a repeated administration had anxiolytic effects tested by the burying behavior test (Fernandez-Guasti and Martinez-Mota, 2005). A possible mechanism can include the androgen receptor, as its blockade has been shown to prevent the testosterone-induced anxiolysis. Similar results were obtained in our experiment. However, the anxiolytic effect was observed only in the light-dark box. We were not able to reproduce the anxiolytic effects of testosterone in the elevated plus maze and in the open field (Hodosy et al., 2012). On the other hand, flutamide alone had anxiolytic effects in the open field. This suggests that the association between testosterone and anxiety might not be linear. A number of experiments on gonadectomized rats from the lab of professor Frye further showed that dihydrotestosterone 3-alpha metabolites can be the mediators of testosterone anxiolytic effects (Edinger and Frye, 2004, 2005). In addition, blockade of the dihydrotestosterone transformation to 3-alpha androstanediol by a 3-alpha hydroxysteroid dehydrogenase inhibitor prevented the anxiolysis (Frye and Edinger, 2004). Age-related decline in cognitive and affective functions was associated with lower concentrations of testosterone metabolites in the hippocampus. Again, this effect blocked by administration of 3-alpha metabolites administration (Frye et al., 2010). Another mechanism of anxiolytic effect of testosterone was explained in recently published experiment, where exogenous or endogenous opioids could modulate anxiolysis (Khakpai, 2014). In this study, the gama aminobutyric acid systemthat has been proposed in the past, on the other hand, did not alleviate the anxiety level (Roohbakhsh et al., 2011). An important determinant of the postnatal association between anxiety and testosterone or its metabolites might be prenatal stress. Stress induced during gestation resulted in both, reduced testosterone and increased anxiety of the adult offspring (Walf and Frye, 2012). Taken together, the results are consistent and despite differences in the methodology it seems clear that testosterone reduces anxiety in both genders. Its higher concentrations in men might be the reason for the sex differences in anxiety. However, a very important study in rhesus monkeys showed that pharmacological castration reduced and testosterone supplementation normalized anxiety levels (Suarez-Jimenez et al., 2013). A result that is in contrast to the majority of literature of experiments in rodents. Of course, this discrepancy might be discussed with major differences in the methodology-other behavioral tests, and in the intervention-surgical vs. pharmacologic castration. But in general, experiments on monkeys are more relevant to human behavior and, thus, this study must not be overseen. Some of the animal experiments on testosterone and anxiety are summarized in Table 1.

\section{DEPRESSION}

Although the depressive disorder is more prevalent in females (Bebbington, 1996) when compared to males, the prevalence of depression in males increases with age (Khera, 2013) as plasma testosterone drops. Consequently, many experiments and studies were performed to confirm the causative role of testosterone decline in depression pathogenesis. Indeed, these studies were not triggered by the lone fact of testosterone decline and sex difference in prevalence of depressive disorders. In depressive disorders with decreased libido and low testosterone, the androgen hormone replacement therapy was at least as effective as serotonin reuptake transporters (Kranz et al., 2014). Further it was investigated that testosterone can modulate serotonergic transmission, where serotonin plays a crucial role in depression development (Jovanovic et al., 2014). But it is not only the prevalence of depression that differ between sexes. In a study on opposite sex twins, it has been demonstrated that also the etiology of depression 


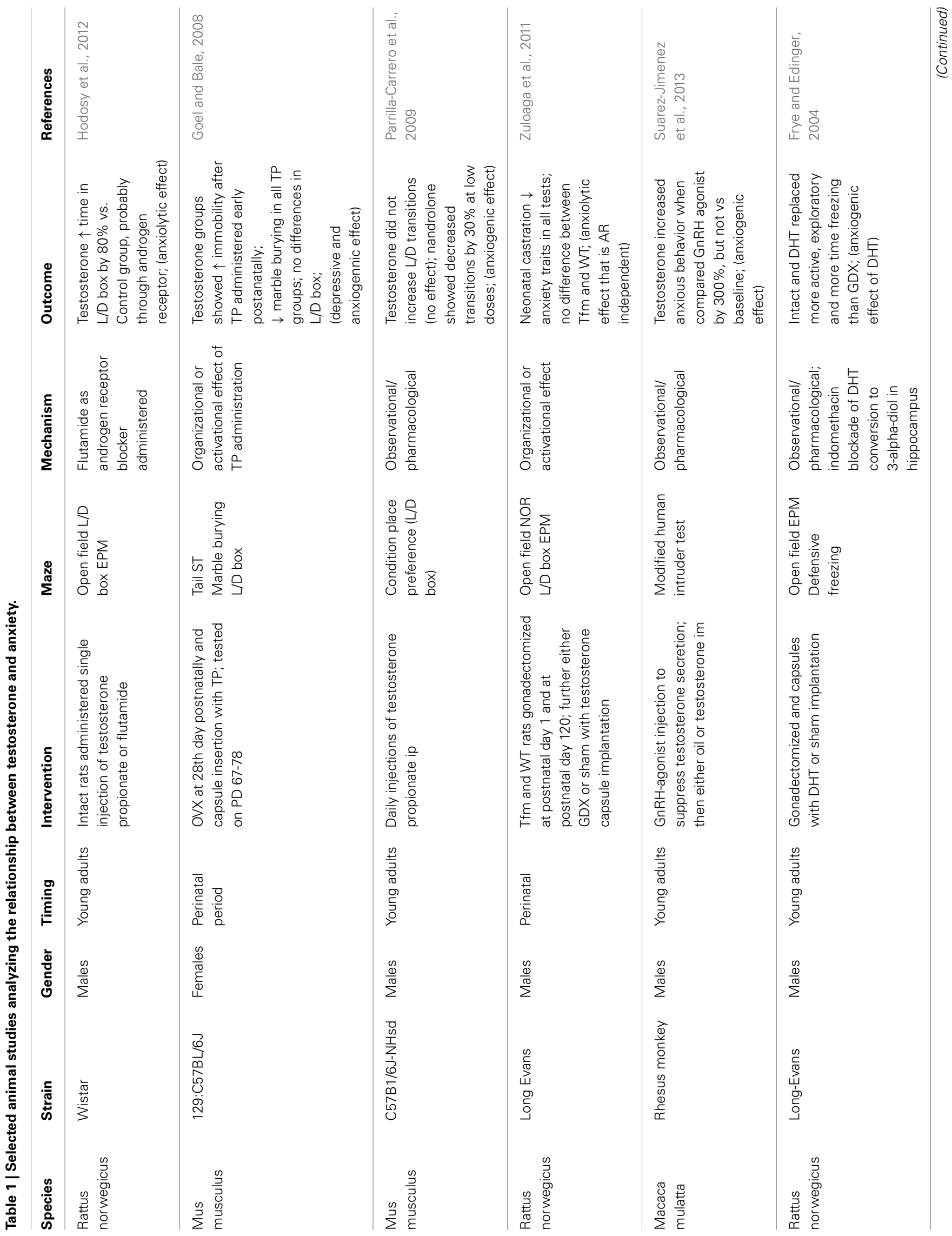




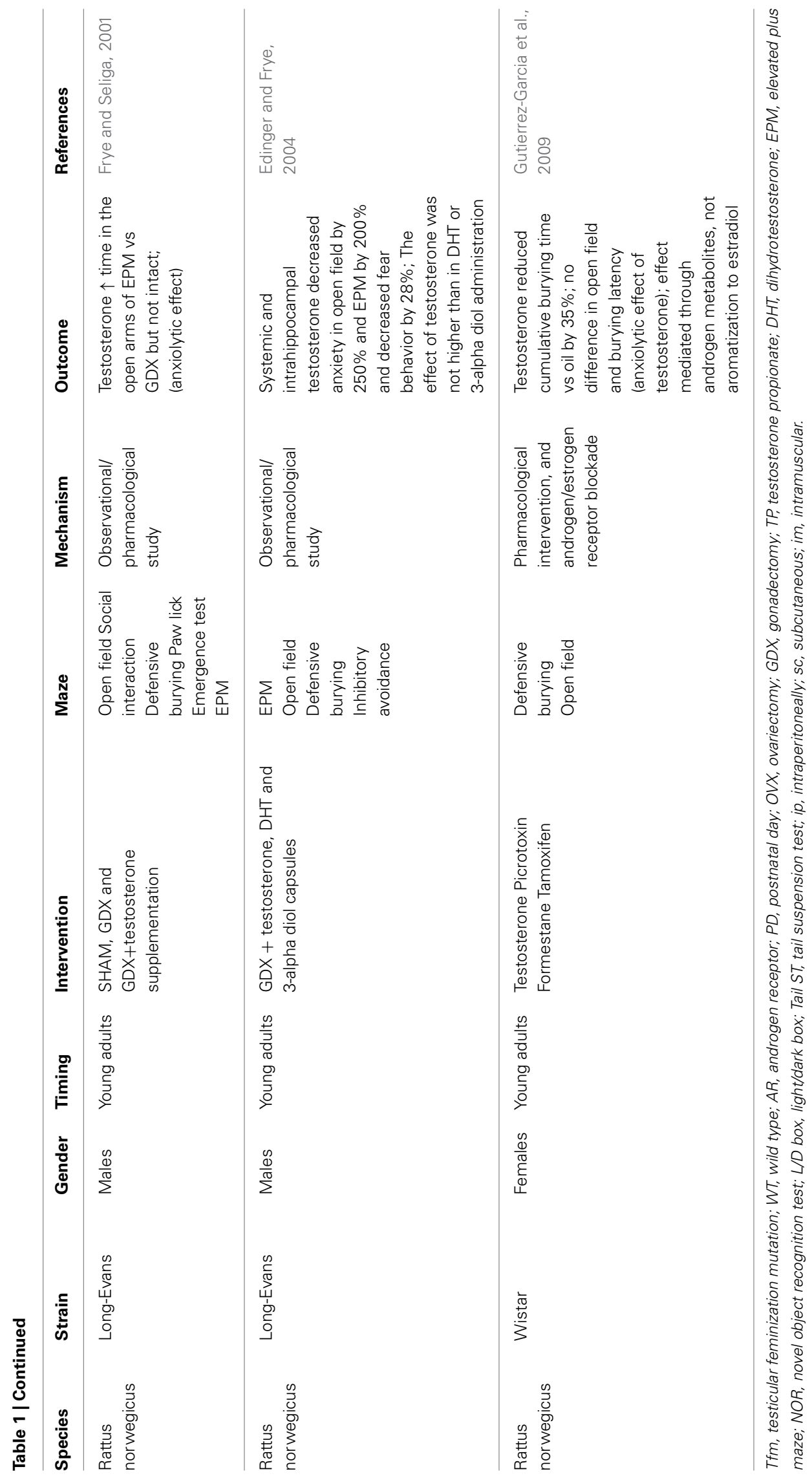


is different in men and women (Kendler and Gardner, 2014). Whether testosterone plays a major role in the sex differences in depression is unclear, but a number of studies indicate that it can affect the mood of depressive patients as well as healthy probands (Mchenry et al., 2014). Nevertheless, it is only one of many biological factors potentially responsible for the sex differences in depression. These were reviewed recently (Altemus et al., 2014). Observational studies on older men revealed that their depressive symptoms are associated with low plasma testosterone (Joshi et al., 2010). Low testosterone and depressive symptoms are both associated with the risk of falls, which are important for life expectancy in the elderly (Kurita et al., 2014). Similarly, in women testosterone concentrations are lower in depressive patients when compared to healthy controls (Kumsar et al., 2014). However, standard antidepressant treatment leads to normalization of testosterone. This suggests that the causality could be different than predicted-depression lowers testosterone. On the other hand, in both men and women, testosterone supplementation leads to improvement of depressive symptoms (Pope et al., 2003; Miller et al., 2009). However, not all interventional studies confirmed the anti-depressant effect of testosterone. At least in one published randomized controlled trial, the effects of testosterone were comparable to placebo effects (Seidman et al., 2001). Similarly, not all observational studies show a consistent picture. At least in one small study, depressive women had higher testosterone (Weber et al., 2000). When publication bias and the high intra- and inter-individual variability of testosterone are taken into account, these small negative or contradictory studies could be even more important. The meta-analyses of the published studies are also to be taken into account. In a meta-analysis of the effects of testosterone on depression, the anti-depressant effect was positive, at least in patients suffering from hypogonadism (Zarrour et al., 2009). The biology of the association between testosterone and depression has been reviewed recently (Mchenry et al., 2014). In an animal model of aging the associated depressive-like behavior correlated with lower testosterone (Egashira et al., 2010). Aged mice of both sexes benefited from testosterone supplementation. In the forced swim test the aged mice treated with testosterone or its metabolites spent less time immobile suggesting that the antidepressant effect of testosterone is mediated via several pathways including the androgen and the estrogen receptor (Frye and Walf, 2009). Another experiment on intact rats revealed that the effect of testosterone on depression is dose-dependent (Buddenberg et al., 2009). Interestingly, similar experiment on gonadectomized rats showed that the testosterone metabolite-3-alpha androstanediol, but not testosterone reverted the depression induced by gonadectomy (Frye et al., 2010). Selected animal experiments on the effects of testosterone on depression are compared in Table 2.

\section{SPATIAL ABILITIES}

Spatial cognitive abilities as well as general cognition and memory decline with aging together with the testosterone levels. During the productive ages and even in early adulthood, men generally outperform women in spatial abilities (Linn and Petersen, 1985). Especially, mental rotation shows a clear sex difference in favor of men. Not surprisingly, observational studies have focused on the association between testosterone and spatial abilities. Some studies have found a positive relationship between testosterone and mental rotation in men (Silverman et al., 1999). Error rate as well as the reaction time negatively correlated with testosterone (Hooven et al., 2004). However, it is not only the actual concentration of testosterone that is studied in relation to spatial performance. Prenatal testosterone and its proxy-the finger length ratio (second to fourth digit) seem to have a stronger association with figure-disembedding and targeting, as additional spatial abilities (Falter et al., 2006). In this study, mental rotation was affected only by sex. In another study, actual testosterone was not associated with spatial abilities, but prenatal testosterone correlated positively with spatial abilities in women (Kempel et al., 2005). In line with these findings is the lack of an association between actual salivary testosterone levels and mental rotation in men and women (Puts et al., 2010). However, in a large observational study analyzing spatial abilities in adult men from various age categories, low testosterone was associated with better spatial visualization (Yonker et al., 2006). In a very interesting study, it was found that in men, the pubertal concentrations of testosterone are negatively associated with mental rotation in the adulthood (Vuoksimaa et al., 2012). In the same paper, the comparison of twins is reported. The twin with higher testosterone scored worse in the mental rotation tests. The results are contradictory, but may depend on the test used for the assessment of spatial abilities. When virtual Morris water maze was used, a positive correlation between testosterone and spatial navigation was found in women, but not in men (Burkitt et al., 2007). The size of the corpus callosum seems to add complexity in the relationship between spatial abilities and testosterone (Karadi et al., 2006). This might be one of the causes for negative findings in studies where some of the determinants are missing (Kubranska et al., 2014). Another cause is likely the selection of the tested population. In gifted children, a negative correlation between salivary testosterone and spatial abilities was found (Ostatnikova et al., 1996). In Chinese men, the accuracy in mental rotation tests was comparable to Americans, but the reaction times were longer indicating that cultural differences could add to the variability of published results (Yang et al., 2007). Last but not least, genetic factors likely modulate the effect of testosterone. We have previously shown that at least in gifted boys, genetic polymorphisms influencing testosterone metabolism affect also its relationship to mental rotation (Celec et al., 2009, 2013). Especially, the CAG short tandem repeat in the exon 1 of the androgen receptor gene seems to be important for the action of testosterone and its metabolites (Nowak et al., 2014). Despite all complexity, the current picture indicates that the association between testosterone and spatial abilities is curvilinear and sex-dependent. In women higher testosterone is associated with better mental rotation, in men lower testosterone is associated with better spatial abilities. This seems to be true both for actual testosterone (Moffat and Hampson, 1996) and for prenatal testosterone (Grimshaw et al., 1995). Supplementation of testosterone in older men results in improvement of spatial abilities, but it is accompanied with changes in estradiol metabolism and it is likely that this interferes with modifications of spatial abilities (Janowsky et al., 1994). Even in rats, testosterone administration affects the strategy of 


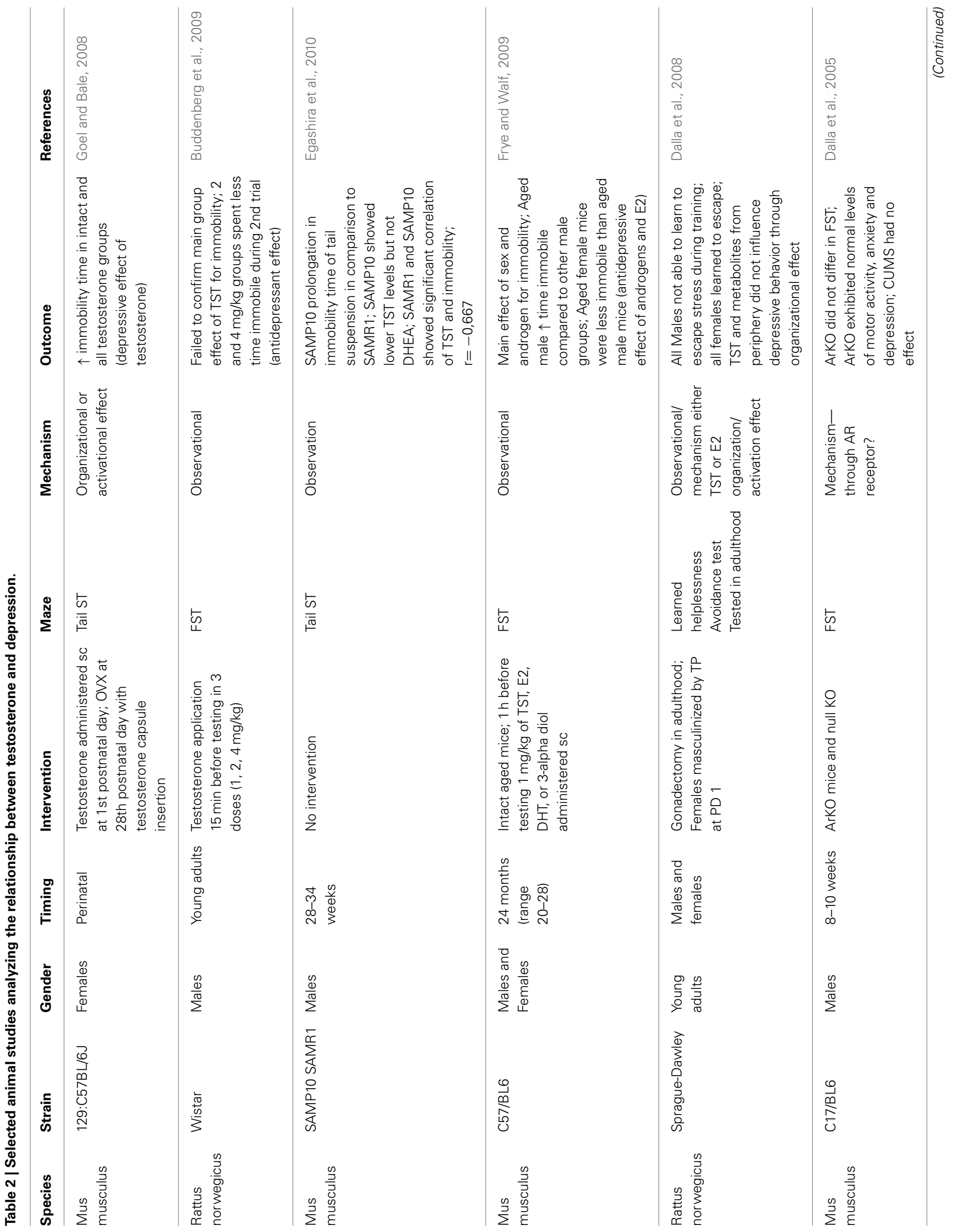




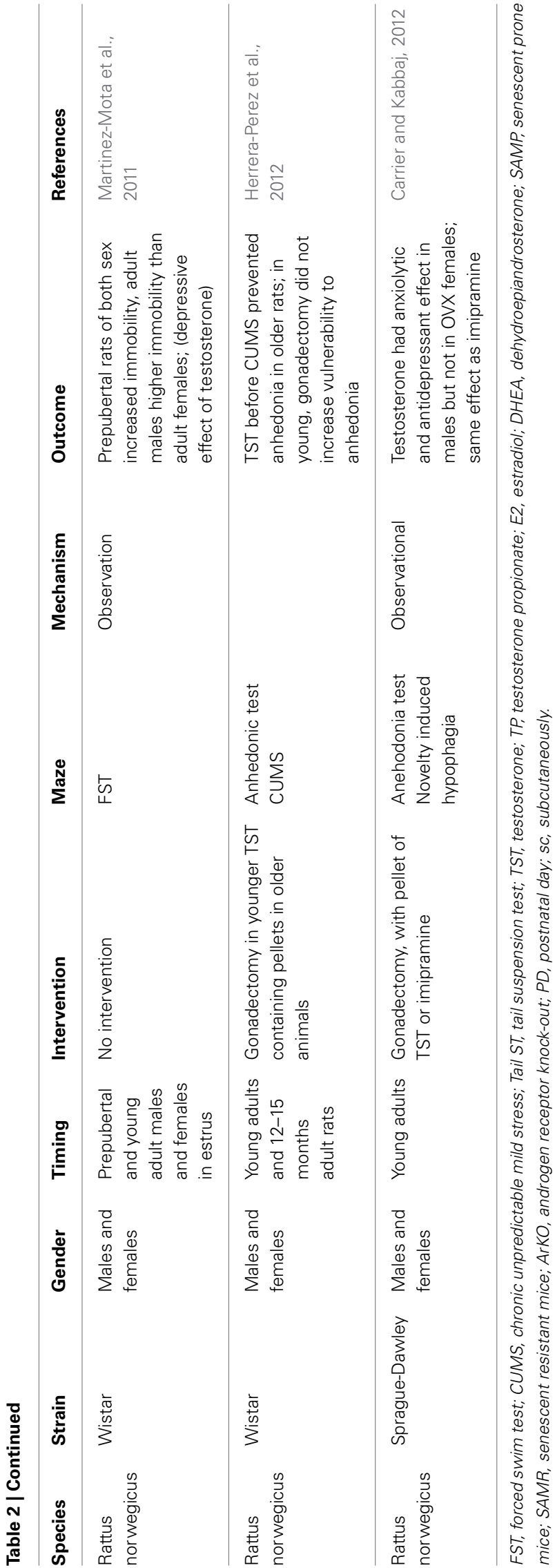

the animals in spatial tasks (Spritzer et al., 2013). However, the interaction between testosterone and mental rotation tests is bidirectional. It has been shown that mental rotation testing affects testosterone, at least in women (Durdiakova et al., 2012). In Table 3, published experimental data on the effects of testosterone on spatial abilities are summarized.

\section{MEMORY}

Women have better verbal memory, while men have an advantage in visual-spatial memory (Lewin et al., 2001). Especially, the difference in spatial memory has been studied in detail (Shah et al., 2013). In a meta-analysis of animal experiments using radial and water mazes, it has been confirmed that males outperform females in spatial memory tasks (Jonasson, 2005). The positive effect of testosterone on memory was, however, well documented in both sexes. Numerous clinical studies in postmenopausal women and men in the andropause showed improvements of learning and memory after testosterone supplementation. Even a short 6-week testosterone treatment resulted in improved spatial and verbal memory of older men (Cherrier et al., 2001). Testosterone has even showed a positive effect on spatial and verbal memory in Alzheimer disease patients (Cherrier et al., 2005). In young women, a single dose of testosterone improved spatial memory (Postma et al., 2000). However, the mechanism of action is unclear, as testosterone is now rather considered as a precursor than as a final hormone. In contrast to some animal experiments, observational studies in elderly men showed that lower testosterone, especially its free fraction was associated with worse visual-spatial memory (Moffat et al., 2002). This might be related to the tasks used, as the testosterone levels in men are related to the learning strategies, especially for spatial memory (Choi and Silverman, 2002). The results are, however, inconsistent. In a study analyzing the effects of a single testosterone injection on elderly men the treatment caused a worsening of verbal memory (Wolf et al., 2000). Similarly, biweekly injections of testosterone during 90 days resulted in memory decline (Maki et al., 2007). In addition, patients with prostate cancer that need hormonal castration via androgen deprivation therapy had worse verbal memory than heathy controls. Interestingly, estradiol-the estrogen metabolite of testosterone reversed the negative effects of androgen deprivation (Beer et al., 2006). Similar findings were found in elderly men and women where estradiol slowed down the age-related memory decline (Carlson and Sherwin, 2000). It seems that the effect of testosterone is dose-dependent and could be curvilinear even within sexes. At least in men, it has been demonstrated that moderate dosing resulted in improved memory, but not low and very high increases of testosterone (Cherrier et al., 2007). Similar results were found in adult male rats where only moderate testosterone doses resulted in spatial memory improvements (Spritzer et al., 2011). A relatively high dose of testosterone had no effect on memory or other analyzed behavioral measures in postmenopausal women in a well-designed and large study (Kocoska-Maras et al., 2011). In another study, women with surgically induced menopause received testosterone or placebo in addition to estrogen supplementation. Testosterone in this case worsened the verbal memory (Moller et al., 2010). A smaller, but longer study on postmenopausal women showed 


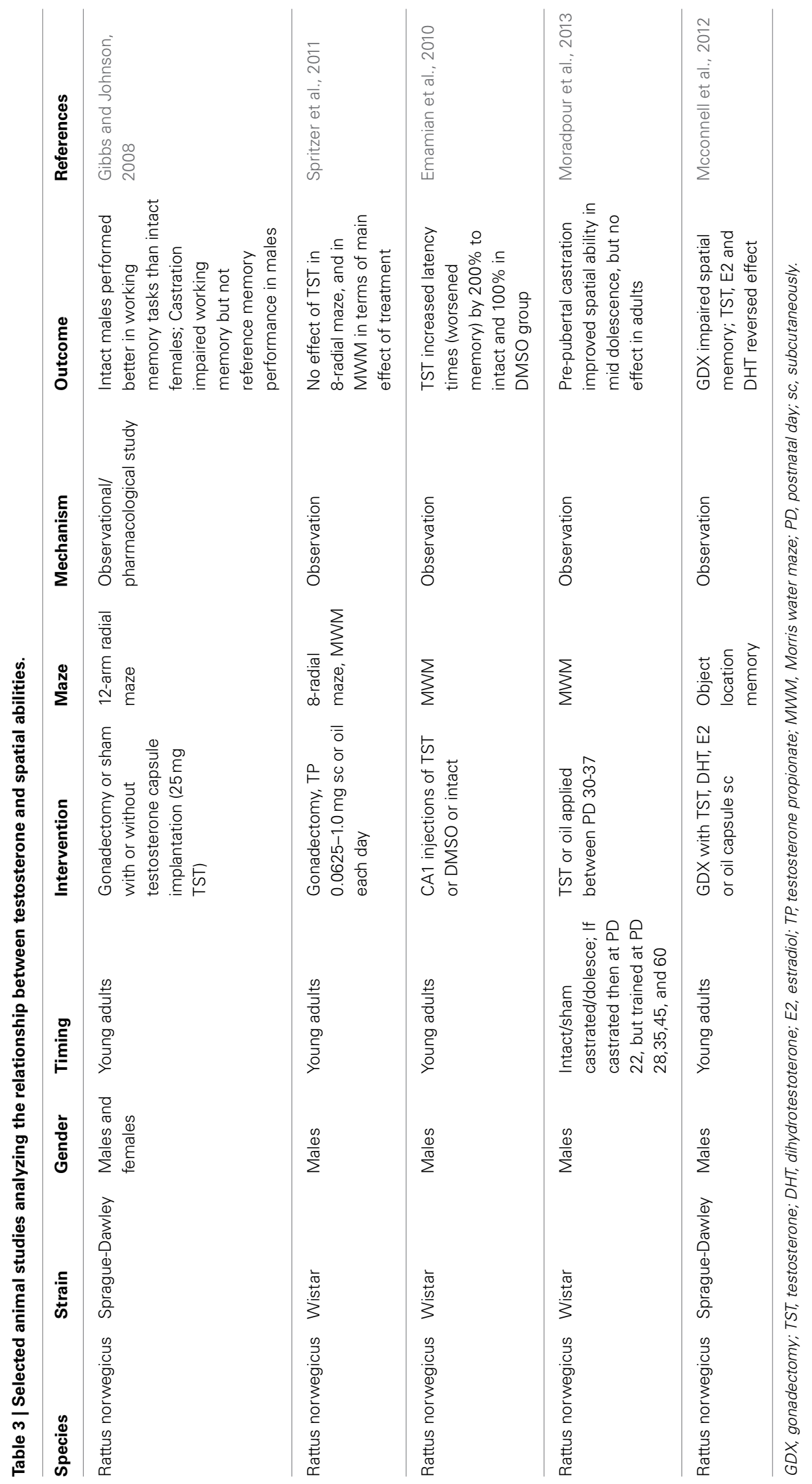


the complete opposite-improvement of verbal memory after testosterone treatment (Davison et al., 2011). Similarly to other behavioral measures memory will be influenced also by prenatal concentrations of testosterone (Bull et al., 2010). This effect might be mediated by the organizational effect of testosterone on brain structures such as amygdala or hippocampus (Ackermann et al., 2012). It has been shown that prenatal and neonatal testosterone affects stress coping and the effects of stress on learning abilities, at least in rodents (Shors and Miesegaes, 2002). Of course, genetic factors might also play a role. At least in one study the APOE genotype interacts with testosterone regarding the influence on age-related cognitive decline (Panizzon et al., 2014). More such studies can be expected in the near future.

Animal experiments help us to uncover the molecular and physiological mechanisms behind the phenotype correlations seen in human studies. The organizational effect of testosterone on the hippocampus, the major memory structure in the brain has been described a long time ago in rats using various mazes (Roof and Havens, 1992; Roof, 1993). In birds, evidence exists for a low testosterone period needed during the development of brain functions such as vocal memory (Korsia and Bottjer, 1991). In aged rats, an important experiment showed that the positive effect was found only when testosterone was administered. The testosterone metabolite, dihydrotestosterone, which cannot be metabolized to estradiol did not showed this effect (Bimonte-Nelson et al., 2003). This indicates that the effect of testosterone on memory is mediated by estradiol and the effect of aromatase which converts testosterone to estradiol. However, in male deer mice it has been shown that aging but not testosterone affects memory (Perrot-Sinal et al., 1998). Testosterone might rather increase synaptic plasticity as shown in rats (Schulz and Korz, 2010). Increased plasticity, however, only enables improved memory. But whether the potential is used depends on other factors including environment and timing and form of learning. Another advantage of animal experiments is the possibility to surgically localize the administration of testosterone into specific brain structures, which is ethically not possible in humans. Such studies showed that in adult male rats administration of any dose of testosterone or the androgen receptor blocker flutamide resulted in worsening of spatial memory (Naghdi et al., 2001). Similar injections of flutamide into amygdala had no effect on spatial memory, but testosterone negatively affected spatial memory and learning (Naghdi et al., 2003). When histological analyses were conducted, it was found that the intrahippocampal injections of testosterone led to an increase in the number of astrocytes in the target area (Emamian et al., 2010). Co-administration of a protein kinase AII inhibitor resulted in a synergistic negative effect on spatial memory (Khorshidahmad et al., 2012). Interestingly, the injection of anastrozole - an aromatase inhibitor resulted in improvement of spatial learning and memory tested in the Morris water maze (Moradpour et al., 2006). This further confirms that the negative effect of testosterone on memory is localized to hippocampus and is mediated by estradiol. When dihydrotestosterone-the androgen metabolite of testosterone was injected into the CA1 region of the hippocampus, spatial memory was improved (Babanejad et al., 2012). Testosterone has very likely an important role in the physiology of brain functions, but it might also be useful in some pathologies. In castrated rats, testosterone was able to reverse the ethanol-induced memory deficit (Khalil et al., 2005). In diabetic rats, the memory impairment was partially reversed by testosterone administration as well (Nayebi et al., 2014). An experiment in mice contributed to the growing list of confounding variables with the length of the photoperiod. Castration and supplementation with testosterone had no effect when the photoperiod was long ( $16 \mathrm{~h}$ of light per day). On the contrary, in mice housed with a short photoperiod ( $8 \mathrm{~h}$ of light per day), the effects on spatial memory were clearly seen (Pyter et al., 2006). A selection of the numerous animal experiments focusing on testosterone and memory are presented in Table 4.

\section{FUNCTIONAL MAGNETIC RESONANCE IMAGING IN HUMANS}

Functional magnetic resonance imaging (fMRI) is a neuroimaging procedure that uses MRI technology for measuring the brain activity. The principle lies in detection of associated changes in blood flow and is useful in mapping the brain functional areas (Hofer et al., 2013). Several studies were performed using human volunteers for spatial tasks, memory as well as mood disorders/traits.

As for spatial tasks and mental rotation, the fMRI data are valuably consistent. In line with the previous studies, the males outperformed females in spatial tasks. Additionally, the fMRI showed stronger activation of left inferior parietal lobe in males compared to females. Also, the testosterone levels correlated with activation levels during mental rotation task in males. In females, the early follicular and midluteal phases were associated with better outcome and higher estradiol concentrations (Schoning et al., 2007). Likewise, a study of van Hemmen et al. confirmed previously reported sex differences in neural activation during mental rotation. Moreover, participants with complete androgen insensitivity syndrome presented with female-like neural activation pattern in the parietal lobe, indicating that gonadal hormone exposure rather than genetic sex itself plays role in brain functions (Van Hemmen et al., 2014). The menstrual cycle and thus the involvement of sex hormones, including testosterone, in spatial abilities was further confirmed by Pletzer et al. In their study, error rates linked with deactivation of inferior parietal lobes and prefrontal lobes were higher during luteal phase for verbal tasks, while in the follicular phase, spatial abilities in females were confirmed (Pletzer et al., 2011).

\section{ISSUES}

\section{PSYCHOMETRIC TESTS}

The analysis of behavior is not as straightforward as biochemical and molecular methods. Several alternatives exist for testing any brain function. However, the tests are variable and it is only a consensus, which can or should be used. The same applies to mazes used for the assessment of animal behavior. Even for the widely used Morris water maze several alternatives exist and numerous different parameters are used in the particular studies. An experiment showed that testosterone does not affect some of the measures analyzed in the water maze, but does affect other measures such as spatial working memory retention (Sandstrom et al., 2006). 
Table 4 | Selected animal studies analyzing the relationship between testosterone and memory.

\begin{tabular}{lll}
\hline Main objective & Method & Result \\
\hline $\begin{array}{ll}\text { Whether long term TST restoration } \\
\text { improves vasopressin innervations and } \\
\text { spatial learning memory }\end{array}$ & $\begin{array}{l}\text { Three groups of male rats by age } \\
\text { (young, middle aged and senescent) } \\
\text { treated with TST or sham in MWM }\end{array}$ & $\begin{array}{l}\text { TST treatment did not improve spatial } \\
\text { learning or retention of spatial } \\
\text { information. Aged rats performed worse } \\
\text { than young }\end{array}$
\end{tabular}

If testosterone improves spatial abilities in adulthood, when administered neonatally

Spatial learning and circulatory levels of testosterone in plasma
Testosterone propionate applied to neonatal rats; males and females, tested in adulthood

Males and females of Meadow voles according to TST and E levels underwent MWM
TST increased performance in control group males outperformed females, in TST group the pattern was reversed
Roof, 1993

Male superiority was evident only with
high estradiol female group, no difference between high and low TST groups
Whether TST treatment neonatally affects spatial leasing in adulthood in gonadectomized rats with frontal cortical lesion
Neonatally gonadectomized rats (females and males) with or without testosterone treatment underwent MWM in adulthood

If chronic administration of anabolic-androgenic steroids improve spatial cognition

Investigate the effect of reproductive status on spatial learning in several reproductive stages
Three groups of males supplemented with nandrolone, oil and steroid cocktail for 12 weeks, then MWM
Lesions at day 7 did not impair spatial learning but gonadectomy or testosterone propionate impaired the learning
Galea et al., 1995

No differences in spatial tasks in any of the treated groups
Kolb and Stewart, 1995
Meadow voles and deer mice tested in MWM either in breeding or non-breeding stage in adulthood or as juvenile
Better performance of males when females in estrus, otherwise no difference; High-E females performed worse than low-E females or males. No difference until adulthood
How testosterone supplementation influences spatial learning after frontal lesions in both sexes
Eight groups in experiment, females (treated with testosterone or vehicle) and males (gonadectomized or sham), all groups moreover either with frontal cortex lesion or sham
No difference of sex or hormonal manipulation, but males with lesion performed better than females with lesion
Clark et al., 1995

Galea et al., 1996
Four groups of deer mice divided by age performed in MWM. Mice were divided according to breeding state
Young and young breeding mice performed better (higher TST) than old and even young non-breeding (lower TST) mice
Forgie and Kolb, 1998
Spatial learning in male deer mice in relation to age
TST and DHT females, EB females and flutamide males with prenatally (day 16) treatment were tested in adulthood in

MWM

If prenatal androgen and estrogen affects adult spatial learning
If there is difference in spatial memory in females through oestrus

Male and female rats tested in MWM during several estrus cycles
TST and EB sex differences observed in Isgor and Sengelaub, MWM as a prenatal component 1998
Perrot-Sinal et al. 1998

\begin{tabular}{|c|c|c|c|}
\hline $\begin{array}{l}\text { Testosterone and flutamide effect on } \\
\text { spatial performance }\end{array}$ & $\begin{array}{l}\text { Intrahippocampal administration of TST } \\
\text { or flutamide } 30 \text { min prior testing in } \\
\text { MWM }\end{array}$ & $\begin{array}{l}\text { Increased latencies in both treated } \\
\text { groups, dose dependent }\end{array}$ & Naghdi et al., 2001 \\
\hline
\end{tabular}

(Continued) 
Table 4 | Continued

\begin{tabular}{lll}
\hline Main objective & Method & Result \\
\hline $\begin{array}{lll}\text { Developmental androgen sensitivity of } \\
\text { CA3 area and spatial performance }\end{array}$ & $\begin{array}{l}\text { Neonatally TST or ovariectomized } \\
\text { females and TST castrated and TST } \\
\text { treated or not performed in MWM } \\
\text { during adulthood }\end{array}$ & low androgen groups \\
& Isgor and Sengelaub, & 2003
\end{tabular}

If testosterone and flutamide in amygdale affect the spatial abilities
Testosterone or flutamide administered into amygdale 30 min prior testing in MWM

If testosterone improves cognition in older rats

If testosterone improves spatial cognition in female rats
Young and old TST or DHT treated rats underwent water radial maze

TST, DHT, Estradiol or control ovariectomized female rats tested after 48 $\mathrm{h}$ in MWM
Testosterone dose dependent increase in latency times, no effect of flutamide

TST (but not DHT) improved spatial memory in older rats

Estradiol impaired spatial acquisition. TST and DHT without effect

Naghdi et al., 2003

\section{Bimonte-Nelson} et al., 2003

Frick et al., 2004 $\begin{array}{ll}\text { Males control outperformed females; } & \text { Jones and Watson, } \\ \text { Tfm showed intermediate performance } & 2005\end{array}$ heterozygote females performed in Tfm showed intermediate performance 2005 water maze

Male rats castrates with ethanol, testosterone or both performed in water maze

Ethanol induced deficits in spatial Khalil et al., 2005

Evaluate effects of testosterone and ethanol on spatial cognition

Role of testicular hormones on spatial abilities

\section{Castrated and intact males performed} in MWM and delayed-matching-to-place MWM

Mice either in 16 or $8 \mathrm{~h}$ daylight for 14 weeks performed in MWM after castration/sham/castration+ testosterone

If photoperiod affects spatial learning through testosterone reduction

Evaluate effect of TST, estrogen and anastrazol on spatial abilities

CA1 cannulation of adult male rats with various dosages of testosterone, estradiol, anastrazol or DMSO cognition; testosterone reversed this effect

$\begin{array}{ll}\text { Castration impaired working memory } & \text { Sandstrom et al., } \\ \begin{array}{l}\text { retention, reversed by exogenous } \\ \text { testosterone }\end{array} & 2006\end{array}$

Castrated with testosterone short day

Pyter et al., 2006 mice performed better to other short day mice, in long day no differences

TST and estradiol impaired spatial learning, anastrazol improved it

Moradpour et al., 2006

No differences between groups

Spritzer et al., 2008

If castration of males affects the spatial memory

Castrated and sham male rats performed in MWM

Spatial learning and TST

Castrated and intact male rats, rats cannulated into right or left

Castration did not affect learning

Mohaddes et al., 2009

hippocampus castrated or not did spatial task in MWM

Investigate effects of TST metabolites on spatial performance

Male rats subjected to orchiectomy and capsule with TST metabolites implanted 3-alpha and 3-beta-diols enhanced Osborne et al., 2009 did spatial tasks in MWM

Enhancement of aged female rats by androgen supplementation

Old mice with implanted TST or DHT or empty capsules performed in MWM after 6 weeks

\section{spatial cognition}

TST improved spatial cognition, DHT did not

Benice and Raber, 2009

TST, testosterone; DHT, dihydrotestoterone; EB, estradiol benzoate; Tfm, testicular feminization mutation; DMSO, dimethytlsulfoxide; MWM, Morris water maze.

\section{POPULATIONS}

One of the major factors that might explain the differences between the results of various studies is the variability of the examined populations. As mentioned above, the cultural differences, sex and age have all been shown to impact the physiological effects of testosterone. In animal experiments, chosen species and the particular strain is also of importance. Looking at the studies in non-human primates in contrast to the majority of rodent studies the results are mostly negative. For example, testosterone manipulations in rhesus monkeys did not alter their working and 
reference memory, although emotional processing was affected. Indeed, the treatment for testosterone might have not last long enough to affect the cognition (Kelly et al., 2014). Other possible explanations might be due to low number of animals included, but also to physiological differences including body size and the concluding testosterone kinetics (King et al., 2012). Specific behavioral tests might also be responsible for the differences observed (Lacreuse et al., 2012).

\section{TESTOSTERONE MEASUREMENT}

There are several possibilities as to what kind of biological samples should be used for the testosterone measurement. Plasma, saliva, urine are available and all have some strengths and weaknesses. The simple scheme of free-bioactive fraction of testosterone that should be assessed using salivary testosterone or plasma albumin and sex hormone binding globulin is not correct. Bound testosterone has its effects on target tissues and it is not clear which of the potential biological liquids is robust against technical and biological variability. One of the exotic possibilities is measurement of testosterone in the hair. The concentration in the hair might, however, be relevant as it integrates all the intra-individual variability of testosterone (Dettenborn et al., 2013).

\section{TIMING}

Testosterone undergoes several biorhythms. In some studies, even the best-known circadian rhythm is not taken into account. Implants that slowly release testosterone totally ignore daily variations that occur physiologically. Other rhythms such as infradian cycles are completely forgotten when experiments are designed. But beyond cyclic variations, testosterone undergoes chaotic temporary changes that are usually described as noise. Although such research is lacking, it might be that it has some physiological role similarly to heart rhythm variability. In addition, the timing of behavioral analyses is of importance. While within $30 \mathrm{~min}$ after administration, non-genomic effects are important, later genomic effects are expected to be the major mediator. But this does not have to be true. Even later, the non-genomic effects are active in parallel with the gene expression changes. Only the study of the particular effects is more and more complicated, especially due to the complex kinetics of testosterone and the complex abilities being tested as proved in a focused experiment (Hawley et al., 2013). Additionally, physiological and also behavioral functions are exerted on a rhythmic basis. Timing the behavioral tests for light phase, while rodents usually are active during night can represent a major problem in animal behavior testing. Moreover, the central circadian clock is located in the suprachiasmatic nucleus of the hypothalamus and it receives signals directly from photoreceptors. GABA is thought to play a major role in coordinating the synchronized firing of suprachiasmatic neurons (Urbanski, 2011). However, steroid hormones may also exert their nongenomic function through GABA receptors. Disrupting the GABAergic system by untimed testosterone application, may be one other reason for controversy results in behavioral analysis. Alternatively, aging is strongly related to decline of circulating sex hormones, disrupting thus also circadian rhythms and leading to impaired sleep or cognitive functioning (Urbanski et al., 2014). Restoring natural circulating hormone pattern in older but also in younger animals could possibly lead also to more comprehensive results of sex hormones and behavior studies.

\section{ADMINISTRATION ROUTE}

In most studies, testosterone is injected via i.p. or i.m. injections, but there are indices that to study the effects of testosterone on brain functions, the steroid has to be injected directly into the target brain structure. At least in one experiment directly comparing peripheral administration and intrahippocampal injections of testosterone it was shown that the peripheral route had no effect on learning and memory while central injections were effective (Harooni et al., 2008).

\section{TYPE OF TESTOSTERONE USED}

Testosterone in the experiments is sometimes used as butyrate, decanoate, undecanoate etc. These pharmacological forms have, however, variable kinetics and might therefore have also variable effects, especially in the brain, where the kinetics is of special importance (Filova et al., 2012). Dosing of testosterone seems to be of enormous importance. It varies between the experiments widely and should always be taken into account when evaluating the results. In experiments, moderate, but not very low or very high doses of testosterone had some effect on behavioral measures such as memory (Spritzer et al., 2011).

The effect of testosterone is influenced by several factors, but only some of them are known. These include genetic polymorphisms related to testosterone metabolism or other pathways related to cognitive functioning (Panizzon et al., 2014). Next generation sequencing and lower prices of genotyping will enable detailed studies focusing on the genetic factors and especially on the complex interactions between genetic, endocrine and other environmental factors.

\section{METABOLISM}

Testosterone is currently seen more as a precursor of hormones. In most target tissues, testosterone is converted into metabolites such as dihydrotestosterone-a more potent androgen receptor ligand. The enzyme aromatase, on the other hand, can metabolize testosterone into estradiol-a ligand of the estrogen receptors. Further metabolites are being added to the list. But in general, it is of importance to recognize the role of the target tissue that can convert testosterone to inducers of very different signaling pathways. Without genetic or pharmacologic manipulation it is not possible to distinguish the effects when testosterone itself is administered.

\section{NON-GENOMIC EFFECTS}

The metabolism of testosterone makes studying the physiology of testosterone effects on the brain difficult. But the response of target tissues are similarly complex. Testosterone can be recognized by the androgen receptor inducing genomic effects - changes in gene expression. But the same testosterone can induce other signaling pathways that do not require changes in the use of the genomic information. These effects are called non-genomic and are studied for all steroid hormones. When testosterone is injected into the hippocampus together with a protein synthesis inhibitor that prevents genomic effects, spatial memory is improved in 
male rats (Naghdi et al., 2005). This points toward the possibility that non-genomic effects can be opposite to the genomic effects. But it also shows that doing such experiments and interpreting their results is difficult. Inhibition of protein synthesis is of course not specific. An alternative is to analyze the behavior rapidly after testosterone injection, as it take roughly $30 \mathrm{~min}$ to induce gene expression changes. But the kinetics of testosterone in vivo complicates the interpretation. Another option is the co-administration of androgen receptor and estrogen receptor blockers.

\section{CONCLUSION AND FUTURE OUTLOOK}

While fMRI results bring interesting data and knowledge on behavioral traits and spatial abilities in relation to testosterone levels and sex differences, the result obtained can show only association or correlation but not causal relationship of testosterone effect on behavior. Nevertheless, also according to the numerous published studies and animal experiments, testosterone seems to affect brain functions. The high number of relevant publications also indicates that it is a hot topic of interest. However, quantity is not quality and currently, despite numerous publications it is very difficult to conclude how testosterone affects cognitions and emotions. Most of the published literature agrees on the fact that testosterone is anxiolytic, anti-depressant and improves spatial abilities. But this picture is oversimplified. Many variables add to the complex interactions between testosterone and the brain. Memory, both, verbal and spatial, is a good example. Age, sex, current endocrine status, but also the timing of testosterone analysis or administration, status of the target tissues and several other factors influence the outcome of observational or interventional studies. It is, thus, clear that small studies can only describe a very small window of the whole complex physiology. Analyzing testosterone concentrations, choosing appropriate doses and pharmacological forms is difficult enough. The psychometrics behind behavioral tests in animal experiments and behind psychological tests in human studies is, nevertheless, lacking. Standardization in this area would surely improve our understanding of the neuroendocrinology of testosterone. More systematic research using the whole spectrum of available tools and looking at the various physiological aspects is needed. However, to be able to publish such research, journals should accept manuscripts based on the design and not on the results. Otherwise, the publication bias that is obvious in the so far published literature will continue to be a big issue. Many researchers in this field complain about negative results that are very difficult to publish in the relevant journals. The number of such unpublished observations and experiments is unknown. But based on our humble experience, the negative results will probably be more common than the published positive ones. And if the contradictory published findings are added, the picture gets even more confusing. Large systematic research projects with more cooperation between the most productive research teams is definitely needed.

\section{ACKNOWLEDGMENTS}

This publication is the result of the implementation of the project University Science Park of Comenius University in Bratislava (ITMS 26240220086) supported by the Research and
Development Operational Programme funded by the European Regional Development Fund.

\section{REFERENCES}

Ackermann, S., Spalek, K., Rasch, B., Gschwind, L., Coynel, D., Fastenrath, M., et al. (2012). Testosterone levels in healthy men are related to amygdala reactivity and memory performance. Psychoneuroendocrinology 37, 1417-1424. doi: 10.1016/j.psyneuen.2012.01.008

Aikey, J. L., Nyby, J. G., Anmuth, D. M., and James, P. J. (2002). Testosterone rapidly reduces anxiety in male house mice (Mus musculus). Horm. Behav. 42, 448-460. doi: 10.1006/hbeh.2002.1838

Altemus, M., Sarvaiya, N., and Epperson, C. N. (2014). Sex differences in anxiety and depression clinical perspectives. Front. Neuroendocrinol. 35:4. doi: 10.1016/j.yfrne.2014.05.004

Babanejad, S., Naghdi, N., and Haeri Rohani, S. A. (2012). Microinjection of dihydrotestosterone as a 5alpha-reduced metabolite of testosterone into CA1 region of hippocampus could improve spatial learning in the adult male rats. Iran J. Pharm. Res. 11, 661-669.

Basaria, S. (2013). Reproductive aging in men. Endocrinol. Metab. Clin. North Am. 42, 255-270. doi: 10.1016/j.ecl.2013.02.012

Bebbington, P. (1996). The origins of sex differences in depressive disorder: bridging the gap. Int. Rev. Psychiatry 8, 295-332. doi: 10.3109/09540269609 051547

Beer, T. M., Bland, L. B., Bussiere, J. R., Neiss, M. B., Wersinger, E. M., Garzotto, M., et al. (2006). Testosterone loss and estradiol administration modify memory in men. J. Urol. 175, 130-135. doi: 10.1016/S0022-5347(05)00049-2

Benice, T. S., and Raber, J. (2009). Testosterone and dihydrotestosterone differentially improve cognition in aged female mice. Learn. Mem. 16, 479-485. doi 10.1101/lm.1428209

Bimonte-Nelson, H. A., Singleton, R. S., Nelson, M. E., Eckman, C. B., Barber, J., Scott, T. Y., et al. (2003). Testosterone, but not nonaromatizable dihydrotestosterone, improves working memory and alters nerve growth factor levels in aged male rats. Exp. Neurol. 181, 301-312. doi: 10.1016/S0014-4886(03) 00061-X

Buddenberg, T. E., Komorowski, M., Ruocco, L. A., Silva, M. A., and Topic, B. (2009). Attenuating effects of testosterone on depressive-like behavior in the forced swim test in healthy male rats. Brain Res. Bull. 79, 182-186. doi: 10.1016/j.brainresbull.2009.02.008

Bull, R., Davidson, W. A., and Nordmann, E. (2010). Prenatal testosterone, visualspatial memory, and numerical skills in young children. Learn. Individ. Differ. 20, 246-250. doi: 10.1016/j.lindif.2009.12.002

Burger, H. G. (2002). Androgen production in women. Fertil. Steril. 77(Suppl. 4), S3-S5. doi: 10.1016/S0015-0282(02)02985-0

Burkitt, J., Widman, D., and Saucier, D. M. (2007). Evidence for the influence of testosterone in the performance of spatial navigation in a virtual water maze in women but not in men. Horm. Behav. 51, 649-654. doi: 10.1016/j.yhbeh.2007.03.007

Cahill, L. (2014). Equal not equal the same: sex differences in the human brain. Cerebrum 2014:5.

Camacho, E. M., Huhtaniemi, I. T., O’neill, T. W., Finn, J. D., Pye, S. R., Lee, D. M., et al. (2013). Age-associated changes in hypothalamic-pituitary-testicular function in middle-aged and older men are modified by weight change and lifestyle factors: longitudinal results from the European male ageing study. Eur. J. Endocrinol. 168, 445-455. doi: 10.1530/EJE-12-0890

Carlson, L. E., and Sherwin, B. B. (2000). Higher levels of plasma estradiol and testosterone in healthy elderly men compared with age-matched women may protect aspects of explicit memory. Menopause 7, 168-177. doi: 10.1097/00042192-200007030-00007

Carrier, N., and Kabbaj, M. (2012). Testosterone and imipramine have antidepressant effects in socially isolated male but not female rats. Horm. Behav. 61, 678-685. doi: 10.1016/j.yhbeh.2012.03.001

Celec, P., Ostatnikova, D., Holesova, Z., Minarik, G., Ficek, A., Kelemenova, S., et al. (2009). Spatial abilities in prepubertal intellectually gifted boys and genetic polymorphisms related to testosterone metabolism. J. Psychophysiol. 23, 1-6. doi: $10.1027 / 0269-8803.23 .1 .1$

Celec, P., Tretinárová, D., Minárik, G., Ficek, A., Szemes, T., Lakatošová, S., et al. (2013). Genetic polymorphisms related to testosterone metabolism in intellectually gifted boys. PLoS ONE 8:e54751. doi: 10.1371/journal.pone.0054751 
Cherrier, M. M., Asthana, S., Plymate, S., Baker, L., Matsumoto, A. M., Peskind, E., et al. (2001). Testosterone supplementation improves spatial and verbal memory in healthy older men. Neurology 57, 80-88. doi: 10.1212/WNL.57.1.80

Cherrier, M. M., Matsumoto, A. M., Amory, J. K., Asthana, S., Bremner, W., Peskind, E. R., et al. (2005). Testosterone improves spatial memory in men with Alzheimer disease and mild cognitive impairment. Neurology 64, 2063-2068. doi: 10.1212/01.WNL.0000165995.98986.F1

Cherrier, M. M., Matsumoto, A. M., Amory, J. K., Johnson, M., Craft, S., Peskind, E. R., et al. (2007). Characterization of verbal and spatial memory changes from moderate to supraphysio logical increases in serum testosterone in healthy older men. Psychoneuroendocrinology 32, 72-79. doi: 10.1016/j.psyneuen.2006.10.008

Choi, J., and Silverman, I. (2002). The relationship between testosterone and routelearning strategies in humans. Brain Cogn. 50, 116-120. doi: 10.1016/S02782626(02)00015-5

Clark, A. S., Mitre, M. C., and Brinck-Johnsen, T. (1995). Anabolic-androgenic steroid and adrenal steroid effects on hippocampal plasticity. Brain Res. 679, 64-71. doi: 10.1016/0006-8993(95)00202-2

Dalla, C., Antoniou, K., Papadopoulou-Daifoti, Z., Balthazart, J., and Bakker, J. (2005). Male aromatase-knockout mice exhibit normal levels of activity, anxiety and "depressive-like" symptomatology. Behav. Brain Res. 163, 186-193. doi: 10.1016/j.bbr.2005.04.020

Dalla, C., Edgecomb, C., Whetstone, A. S., and Shors, T. J. (2008). Females do not express learned helplessness like males do. Neuropsychopharmacology 33, 1559-1569. doi: 10.1038/sj.npp.1301533

Davison, S. L., Bell, R. J., Gavrilescu, M., Searle, K., Maruff, P., Gogos, A., et al. (2011). Testosterone improves verbal learning and memory in postmenopausal women: results from a pilot study. Maturitas 70, 307-311. doi: 10.1016/j.maturitas.2011.08.006

Dettenborn, L., Hinkelmann, K., Muhtz, C., Gao, W., Wingenfeld, K., Spitzer, C., et al. (2013). Hair testosterone and visuospatial memory in middle-aged men and women with and without depressive symptoms. Psychoneuroendocrinology 38, 2373-2377. doi: 10.1016/j.psyneuen.2013.03.011

Dohle, G. R., Smit, M., and Weber, R. F. (2003). Androgens and male fertility. World J. Urol. 21, 341-345. doi: 10.1007/s00345-003-0365-9

Durdiakova, J., Hodosy, J., Kubranska, A., Ostatnikova, D., and Celec, P. (2012). The effect of mental rotation on changes in plasma testosterone and cortisol levels. Cent. Eur. J. Biol. 7, 1005-1012. doi: 10.2478/s11535-012-0084-6

Edinger, K. L., and Frye, C. A. (2004). Testosterone's analgesic, anxiolytic, and cognitive-enhancing effects may be due in part to actions of its 5alphareduced metabolites in the hippocampus. Behav. Neurosci. 118, 1352-1364. doi: 10.1037/0735-7044.118.6.1352

Edinger, K. L., and Frye, C. A. (2005). Testosterone's anti-anxiety and analgesic effects may be due in part to actions of its 5 alpha-reduced metabolites in the hippocampus. Psychoneuroendocrinology 30, 418-430. doi: 10.1016/j.psyneuen.2004.11.001

Egashira, N., Koushi, E., Okuno, R., Shirakawa, A., Mishima, K., Iwasaki, K., et al. (2010). Depression-like behavior and reduced plasma testosterone levels in the senescence-accelerated mouse. Behav. Brain Res. 209, 142-147. doi: 10.1016/j.bbr.2010.01.030

Emamian, S., Naghdi, N., Sepehri, H., Jahanshahi, M., Sadeghi, Y., and Choopani, S. (2010). Learning impairment caused by intra-CA1 microinjection of testosterone increases the number of astrocytes. Behav. Brain Res. 208, 30-37. doi: 10.1016/j.bbr.2009.11.004

Falter, C. M., Arroyo, M., and Davis, G. J. (2006). Testosterone: activation or organization of spatial cognition? Biol. Psychol. 73, 132-140. doi: 10.1016/j.biopsycho.2006.01.011

Fernandez-Guasti, A., and Martinez-Mota, L. (2005). Anxiolytic-like actions of testosterone in the burying behavior test: role of androgen and GABA-benzodiazepine receptors. Psychoneuroendocrinology 30, 762-770. doi: 10.1016/j.psyneuen.2005.03.006

Filova, B., Majzunova, M., Malinova, M., Ostatnikova, D., Celec, P., and Hodosy, J. (2012). Factors determining the kinetics of a single dose of testosterone in rats. Arch. Biol. Sci. 64, 859-863. doi: 10.2298/ABS1203859F

Filova, B., Ostatnikova, D., Celec, P., and Hodosy, J. (2013). The effect of testosterone on the formation of brain structures. Cells Tissues Organs 197, 169-177. doi: 10.1159/000345567

Forgie, M. L., and Kolb, B. (1998). Sex differences in the effects of frontal cortex injury: role of differential hormonal experience in early development. Behav. Neurosci. 112, 141-153. doi: 10.1037/0735-7044.112.1.141
Frick, K. M., Fernandez, S. M., Bennett, J. C., Prange-Kiel, J., Maclusky, N. J., and Leranth, C. (2004). Behavioral training interferes with the ability of gonadal hormones to increase CAl spine synapse density in ovariectomized female rats. Eur. J. Neurosci. 19, 3026-3032. doi: 10.1111/j.0953-816X.2004. 03427.x

Frye, C. A., and Edinger, K. L. (2004). Testosterone's metabolism in the hippocampus may mediate its anti-anxiety effects in male rats. Pharmacol. Biochem. Behav. 78, 473-481. doi: 10.1016/j.pbb.2004.04.019

Frye, C. A., Edinger, K. L., Lephart, E. D., and Walf, A. A. (2010). 3 alphaandrostanediol, but not testosterone, attenuates age-related decrements in cognitive, anxiety, and depressive behavior of male rats. Front. Aging Neurosci. 2:15. doi: 10.3389/fnagi.2010.00015

Frye, C. A., and Seliga, A. M. (2001). Testosterone increases analgesia, anxiolysis, and cognitive performance of male rats. Cogn. Affect. Behav. Neurosci. 1, 371-381. doi: 10.3758/CABN.1.4.371

Frye, C. A., and Walf, A. A. (2009). Depression-like behavior of aged male and female mice is ameliorated with administration of testosterone or its metabolites. Physiol. Behav. 97, 266-269. doi: 10.1016/j.physbeh.2009.02.022

Furukawa, A., Miyatake, A., Ohnishi, T., and Ichikawa, Y. (1998). Steroidogenic acute regulatory protein (StAR) transcripts constitutively expressed in the adult rat central nervous system: colocalization of StAR, cytochrome P-450SCC (CYP XIA1), and 3beta-hydroxysteroid dehydrogenase in the rat brain. J. Neurochem. 71, 2231-2238. doi: 10.1046/j.1471-4159.1998.71062231.x

Galea, L. A., Kavaliers, M., and Ossenkopp, K. P. (1996). Sexually dimorphic spatial learning in meadow voles Microtus pennsylvanicus and deer mice Peromyscus maniculatus. J. Exp. Biol. 199, 195-200.

Galea, L. A., Kavaliers, M., Ossenkopp, K. P., and Hampson, E. (1995). Gonadal hormone levels and spatial learning performance in the Morris water maze in male and female meadow voles, Microtus pennsylvanicus. Horm. Behav. 29, 106-125. doi: 10.1006/hbeh.1995.1008

Gibbs, R. B., and Johnson, D. A. (2008). Sex-specific effects of gonadectomy and hormone treatment on acquisition of a 12-arm radial maze task by Sprague Dawley rats. Endocrinology 149, 3176-3183. doi: 10.1210/en.2007-1645

Goel, N., and Bale, T. L. (2008). Organizational and activational effects of testosterone on masculinization of female physiological and behavioral stress responses. Endocrinology 149, 6399-6405. doi: 10.1210/en.2008-0433

Goudsmit, E., Van De Poll, N. E., and Swaab, D. F. (1990). Testosterone fails to reverse spatial memory decline in aged rats and impairs retention in young and middle-aged animals. Behav. Neural Biol. 53, 6-20. doi: 10.1016/01631047(90)90729-P

Grimshaw, G. M., Sitarenios, G., and Finegan, J. A. (1995). Mental rotation at 7 years: relations with prenatal testosterone levels and spatial play experiences. Brain Cogn. 29, 85-100. doi: 10.1006/brcg.1995.1269

Gutierrez-Garcia, A. G., Contreras, C. M., Vasquez-Hernandez, D. I., MolinaJimenez, T., and Jacome-Jacome, E. (2009). Testosterone reduces cumulative burying in female Wistar rats with minimal participation of estradiol. Pharmacol. Biochem. Behav. 93, 406-412. doi: 10.1016/j.pbb.2009.06.002

Harooni, H. E., Naghdi, N., Sepehri, H., and Rohani, A. H. (2008). Intra hippocampal injection of testosterone impaired acquisition, consolidation and retrieval of inhibitory avoidance learning and memory in adult male rats. Behav. Brain Res. 188, 71-77. doi: 10.1016/j.bbr.2007.10.017

Hawley, W. R., Grissom, E. M., Martin, R. C., Halmos, M. B., Bart, C. L., and Dohanich, G. P. (2013). Testosterone modulates spatial recognition memory in male rats. Horm. Behav. 63, 559-565. doi: 10.1016/j.yhbeh.2013.02.007

Healy, S. D., Braham, S. R., and Braithwaite, V. A. (1999). Spatial working memory in rats: no differences between the sexes. Proc. Biol. Sci. 266, 2303-2308. doi: 10.1098/rspb.1999.0923

Herrera-Perez, J. J., Martinez-Mota, L., Chavira, R., and Fernandez-Guasti, A. (2012). Testosterone prevents but not reverses anhedonia in middle-aged males and lacks an effect on stress vulnerability in young adults. Horm. Behav. 61, 623-630. doi: 10.1016/j.yhbeh.2012.02.015

Hodosy, J., Zelmanova, D., Majzunova, M., Filova, B., Malinova, M., Ostatnikova, D., et al. (2012). The anxiolytic effect of testosterone in the rat is mediated via the androgen receptor. Pharmacol. Biochem. Behav. 102, 191-195. doi: 10.1016/j.pbb.2012.04.005

Hofer, P., Lanzenberger, R., and Kasper, S. (2013). Testosterone in the brain: neuroimaging findings and the potential role for neuropsychopharmacology. Eur. Neuropsychopharmacol. 23, 79-88. doi: 10.1016/j.euroneuro.2012. 04.013 
Hooven, C. K., Chabris, C. F., Ellison, P. T., and Kosslyn, S. M. (2004). The relationship of male testosterone to components of mental rotation. Neuropsychologia 42, 782-790. doi: 10.1016/j.neuropsychologia.2003.11.012

Isgor, C., and Sengelaub, D. R. (1998). Prenatal gonadal steroids affect adult spatial behavior, CA1 and CA3 pyramidal cell morphology in rats. Horm. Behav. 34, 183-198. doi: 10.1006/hbeh.1998.1477

Isgor, C., and Sengelaub, D. R. (2003). Effects of neonatal gonadal steroids on adult CA3 pyramidal neuron dendritic morphology and spatial memory in rats. J. Neurobiol. 55, 179-190. doi: 10.1002/neu.10200

Janowsky, J. S., Oviatt, S. K., and Orwoll, E. S. (1994). Testosterone influences spatial cognition in older men. Behav. Neurosci. 108, 325-332. doi: 10.1037/07357044.108.2.325

Jonasson, Z. (2005). Meta-analysis of sex differences in rodent models of learning and memory: a review of behavioral and biological data. Neurosci. Biobehav. Rev. 28, 811-825. doi: 10.1016/j.neubiorev.2004.10.006

Jones, B. A., and Watson, N. V. (2005). Spatial memory performance in androgen insensitive male rats. Physiol. Behav. 85, 135-141. doi: 10.1016/j.physbeh.2005.03.023

Joshi, D., Van Schoor, N. M., De Ronde, W., Schaap, L. A., Comijs, H. C., Beekman, A. T. F., et al. (2010). Low free testosterone levels are associated with prevalence and incidence of depressive symptoms in older men. Clin. Endocrinol. 72, 232-240. doi: 10.1111/j.1365-2265.2009.03641.x

Jovanovic, H., Kocoska-Maras, L., Radestad, A. F., Halldin, C., Borg, J., Hirschberg, A. L., et al. (2014). Effects of estrogen and testosterone treatment on serotonin transporter binding in the brain of surgically postmenopausal women-a PET study. Neuroimage 106C, 47-54.

Karadi, K., Kallai, J., Kover, F., Nemes, J., Makany, T., and Nagy, F. (2006). Endogenous testosterone concentration, mental rotation, and size of the corpus callosum in a sample of young Hungarian women. Percept. Mot. Skills 102, 445-453. doi: 10.2466/pms.102.2.445-453

Kelly, B., Maguire-Herring, V., Rose, C. M., Gore, H. E., Ferrigno, S., Novak, M. A., et al. (2014). Short-term testosterone manipulations do not affect cognition or motor function but differentially modulate emotions in young and older male rhesus monkeys. Horm. Behav. 66, 731-742. doi: 10.1016/j.yhbeh.2014.08.016

Kempel, P., Gohlke, B., Klempau, J., Zinsberger, P., Reuter, M., and Hennig, J. (2005). Second-to-fourth digit length, testosterone and spatial ability. Intelligence 33, 215-230. doi: 10.1016/j.intell.2004.11.004

Kendler, K. S., and Gardner, C. O. (2014). Sex differences in the pathways to major depression: a study of opposite-sex twin Pairs. Am. J. Psychiatry 171, 426-435. doi: 10.1176/appi.ajp.2013.13101375

Khakpai, F. (2014). The effect of opiodergic system and testosterone on anxiety behavior in gonadectomized rats. Behav. Brain Res. 263, 9-15. doi: 10.1016/j.bbr.2014.01.013

Khalil, R., King, M. A., and Soliman, M. R. (2005). Testosterone reverses ethanolinduced deficit in spatial reference memory in castrated rats. Pharmacology 75, 87-92. doi: 10.1159/000087188

Khera, M. (2013). Patients with testosterone deficit syndrome and depression. Arch. Esp. Urol. 66, 729-736.

Khorshidahmad, T., Tabrizian, K., Vakilzadeh, G., Nikbin, P., Moradi, S., HosseiniSharifabad, A., et al. (2012). Interactive effects of a protein kinase AII inhibitor and testosterone on spatial learning in the Morris water maze. Behav. Brain Res. 228, 432-439. doi: 10.1016/j.bbr.2011.12.028

King, H. M., Kurdziel, L. B., Meyer, J. S., and Lacreuse, A. (2012). Effects of testosterone on attention and memory for emotional stimuli in male rhesus monkeys. Psychoneuroendocrinology 37, 396-409. doi: 10.1016/j.psyneuen.2011. 07.010

King, J. A., Barkley, R. A., Delville, Y., and Ferris, C. F. (2000). Early androgen treatment decreases cognitive function and catecholamine innervation in an animal model of ADHD. Behav. Brain Res. 107, 35-43. doi: 10.1016/S01664328(99)00113-8

Kocoska-Maras, L., Zethraeus, N., Radestad, A. F., Ellingsen, T., Von Schoultz, B., Johannesson, M., et al. (2011). A randomized trial of the effect of testosterone and estrogen on verbal fluency, verbal memory, and spatial ability in healthy postmenopausal women. Fertil. Steril. 95, 152-157. doi: 10.1016/j.fertnstert.2010.05.062

Kolb, B., and Stewart, J. (1995). Changes in the neonatal gonadal hormonal environment prevent behavioral sparing and alter cortical morphogenesis after early frontal cortex lesions in male and female rats. Behav. Neurosci. 109, 285-294. doi: 10.1037/0735-7044.109.2.285
Korsia, S., and Bottjer, S. W. (1991). Chronic testosterone treatment impairs vocal learning in male zebra finches during a restricted period of development. J. Neurosci. 11, 2362-2371.

Kranz, G. S., Wadsak, W., Kaufmann, U., Savli, M., Baldinger, P., Gryglewski, G., et al. (2014). High-dose testosterone treatment increases serotonin transporter binding in transgender people. Biol. Psychiatry. doi: 10.1016/j.biopsych.2014. 09.010. [Epub ahead of print].

Kubranska, A., Lakatosova, S., Schmidtova, E., Durdiakova, J., Celec, P., and Ostatnikova, D. (2014). Spatial abilities are not related to testosterone levels and variation in the androgen receptor in healthy young men. Gen. Physiol. Biophys. 33, 311-319. doi: 10.4149/gpb_2014005

Kumsar, S., Kumsar, N. A., Saglam, H. S., Kose, O., Budak, S., and Adsan, O. (2014). Testosterone levels and sexual function disorders in depressive female patients: effects of antidepressant treatment. J. Sex. Med. 11, 529-535. doi: 10.1111 jsm. 12394

Kurita, N., Horie, S., Yamazaki, S., Otoshi, K., Otani, K., Sekiguchi, M., et al. (2014). Low Testosterone levels, depressive symptoms, and falls in older men: a cross-sectional study. J. Am. Med. Dir. Assoc. 15, 30-35. doi: 10.1016/j.jamda.2013.11.003

Lacreuse, A., Gore, H. E., Chang, J., and Kaplan, E. R. (2012). Short-term testosterone manipulations modulate visual recognition memory and some aspects of emotional reactivity in male rhesus monkeys. Physiol. Behav. 106, 229-237. doi: 10.1016/j.physbeh.2012.02.008

Lewin, C., Wolgers, G., and Herlitz, A. (2001). Sex differences favoring women in verbal but not in visuospatial episodic memory. Neuropsychology 15, 165-173. doi: 10.1037/0894-4105.15.2.165

Linn, M. C., and Petersen, A. C. (1985). Emergence and characterization of sex differences in spatial ability: a meta-analysis. Child Dev. 56, 1479-1498. doi: $10.2307 / 1130467$

Lord, C., Sekerovic, Z., and Carrier, J. (2014). Sleep regulation and sex hormones exposure in men and women across adulthood. Pathol. Biol. (Paris) 62, 302-310. doi: 10.1016/j.patbio.2014.07.005

Maki, P. M., Ernst, M., London, E. D., Mordecai, K. L., Perschler, P., Durso, S. C., et al. (2007). Intramuscular testosterone treatment in elderly men: evidence of memory decline and altered brain function. J. Clin. Endocrinol. Metab. 92, 4107-4114. doi: 10.1210/jc.2006-1805

Martinez-Mota, L., Ulloa, R. E., Herrera-Perez, J., Chavira, R., and FernandezGuasti, A. (2011). Sex and age differences in the impact of the forced swimming test on the levels of steroid hormones. Physiol. Behav. 104, 900-905. doi: 10.1016/j.physbeh.2011.05.027

Mcconnell, S. E., Alla, J., Wheat, E., Romeo, R. D., Mcewen, B., and Thornton, J. E. (2012). The role of testicular hormones and luteinizing hormone in spatial memory in adult male rats. Horm. Behav. 61, 479-486. doi: 10.1016/j.yhbeh.2012.01.003

Mchenry, J., Carrier, N., Hull, E., and Kabbaj, M. (2014). Sex differences in anxiety and depression: role of testosterone. Front. Neuroendocrinol. 35:1. doi: 10.1016/j.yfrne.2013.09.001

Mellon, S. H., Griffin, L. D., and Compagnone, N. A. (2001). Biosynthesis and action of neurosteroids. Brain Res. Brain Res. Rev. 37, 3-12. doi: 10.1016/S01650173(01)00109-6

Michels, G., and Hoppe, U. C. (2008). Rapid actions of androgens. Front. Neuroendocrinol. 29:4. doi: 10.1016/j.yfrne.2007.08.004

Miller, K. K., Perlis, R. H., Papakostas, G. I., Mischoulon, D., Iosifescu, D. V., Brick, D. J., et al. (2009). Low-dose transdermal testosterone augmentation therapy improves depression severity in women. CNS Spectr. 14, 688-694.

Miller, W. L., and Auchus, R. J. (2011). The molecular biology, biochemistry, and physiology of human steroidogenesis and its disorders. Endocr. Rev. 32, 81-151. doi: 10.1210/er.2010-0013

Moffat, S. D., and Hampson, E. (1996). A curvilinear relationship between testosterone and spatial cognition in humans: possible influence of hand preference. Psychoneuroendocrinology 21, 323-337. doi: 10.1016/0306-4530(95) 00051-8

Moffat, S. D., Zonderman, A. B., Metter, E. J., Blackman, M. R., Harman, S. M., and Resnick, S. M. (2002). Longitudinal assessment of serum free testosterone concentration predicts memory performance and cognitive status in elderly men. J. Clin. Endocrinol. Metab. 87, 5001-5007. doi: 10.1210/jc.2002-020419

Mohaddes, G., Naghdi, N., Khamnei, S., Khatami, S., and Haeri, A. (2009). Effect of spatial learning on hippocampal testosterone in intact and castrated male rats. Iran. Biomed. J. 13, 49-58. 
Moller, M. C., Bartfai, A. B., and Radestad, A. F. (2010). Effects of testosterone and estrogen replacement on memory function. Menopause 17, 983-989. doi: 10.1097/gme.0b013e3181dc2e40

Moradpour, F., Naghdi, N., and Fathollahi, Y. (2006). Anastrozole improved testosterone-induced impairment acquisition of spatial learning and memory in the hippocampal CA1 region in adult male rats. Behav. Brain Res. 175, 223-232. doi: 10.1016/j.bbr.2006.08.037

Moradpour, F., Naghdi, N., Fathollahi, Y., Javan, M., Choopani, S., and Gharaylou, Z. (2013). Pre-pubertal castration improves spatial learning during midadolescence in rats. Prog. Neuropsychopharmacol. Biol. Psychiatry 46, 105-112. doi: 10.1016/j.pnpbp.2013.07.005

Naghdi, N., Majlessi, N., and Bozorgmehr, T. (2005). The effect of intrahippocampal injection of testosterone enanthate (an androgen receptor agonist) and anisomycin (protein synthesis inhibitor) on spatial learning and memory in adult, male rats. Behav. Brain Res. 156, 263-268. doi: 10.1016/j.bbr.2004.05.032

Naghdi, N., Nafisy, N., and Majlessi, N. (2001). The effects of intrahippocampal testosterone and flutamide on spatial localization in the Morris water maze. Brain Res. 897, 44-51. doi: 10.1016/S0006-8993(00)03261-3

Naghdi, N., Oryan, S., and Etemadi, R. (2003). The study of spatial memory in adult male rats with injection of testosterone enanthate and flutamide into the basolateral nucleus of the amygdala in Morris water maze. Brain Res. 972, 1-8. doi: 10.1016/S0006-8993(03)02227-3

Nayebi, A. M., Pourrabi, S., and Hossini, S. (2014). Testosterone ameliorates streptozotocin-induced memory impairment in male rats. Acta Pharmacol. Sin. 35, 752-757. doi: 10.1038/aps.2014.6

Nowak, N. T., Diamond, M. P., Land, S. J., and Moffat, S. D. (2014). Contributions of sex, testosterone, and androgen receptor CAG repeat number to virtual Morris water maze performance. Psychoneuroendocrinology 41, 13-22. doi: 10.1016/j.psyneuen.2013.12.003

Osborne, D. M., Edinger, K., and Frye, C. A. (2009). Chronic administration of androgens with actions at estrogen receptor beta have anti-anxiety and cognitive-enhancing effects in male rats. Age (Dordr). 31, 191-198. doi: 10.1007/s11357-009-9114-3

Ostatnikova, D., Laznibatova, J., and Dohnanyiova, M. (1996). Testosterone influence on spatial ability in prepubertal children. Stud. Psychol. (Bratisl). 38, 237-245.

Panizzon, M. S., Hauger, R., Xian, H., Vuoksimaa, E., Spoon, K. M., Mendoza, S. P., et al. (2014). Interaction of APOE genotype and testosterone on episodic memory in middle-aged men. Neurobiol. Aging 35, e1771-e1778. doi: 10.1016/j.neurobiolaging.2013.12.025

Parrilla-Carrero, J., Figueroa, O., Lugo, A., Garcia-Sosa, R., Brito-Vargas, P., Cruz, B., et al. (2009). The anabolic steroids testosterone propionate and nandrolone, but not 17alpha-methyltestosterone, induce conditioned place preference in adult mice. Drug Alcohol Depend. 100, 122-127. doi: 10.1016/j.drugalcdep.2008.09.014

Perrot-Sinal, T. S., Kavaliers, M., and Ossenkopp, K. P. (1998). Spatial learning and hippocampal volume in male deer mice: relations to age, testosterone and adrenal gland weight. Neuroscience 86, 1089-1099. doi: 10.1016/S03064522(98)00131-6

Pletzer, B., Kronbichler, M., Ladurner, G., Nuerk, H. C., and Kerschbaum, H. (2011). Menstrual cycle variations in the BOLD-response to a number bisection task: implications for research on sex differences. Brain Res. 1420, 37-47. doi: 10.1016/j.brainres.2011.08.058

Pope, H. G., Cohane, G. H., Kanayama, G., Siegel, A. J., and Hudson, J. I. (2003). Testosterone gel supplementation for men with refractory depression: a randomized, placebo-controlled trial. Am. J. Psychiatry 160, 105-111. doi: 10.1176/appi.ajp.160.1.105

Postma, A., Meyer, G., Tuiten, A., Van Honk, J., Kessels, R. P. C., and Thijssen, J. (2000). Effects of testosterone administration on selective aspects of objectlocation memory in healthy young women. Psychoneuroendocrinology 25, 563-575. doi: 10.1016/S0306-4530(00)00010-X

Puts, D. A., Cardenas, R. A., Bailey, D. H., Burriss, R. P., Jordan, C. L., and Breedlove, S. M. (2010). Salivary testosterone does not predict mental rotation performance in men or women. Horm. Behav. 58, 282-289. doi: 10.1016/j.yhbeh.2010.03.005

Pyter, L. M., Trainor, B. C., and Nelson, R. J. (2006). Testosterone and photoperiod interact to affect spatial learning and memory in adult male white-footed mice (Peromyscus leucopus). Eur. J. Neurosci. 23, 3056-3062. doi: 10.1111/j.14609568.2006.04821.x
Raber, J., Bongers, G., Lefevour, A., Buttini, M., and Mucke, L. (2002). Androgens protect against apolipoprotein E4-induced cognitive deficits. J. Neurosci. 22, 5204-5209.

Roof, R. L. (1993). Neonatal exogenous testosterone modifies sex difference in radial arm and Morris water maze performance in prepubescent and adult rats. Behav. Brain Res. 53, 1-10. doi: 10.1016/S0166-4328(05)80261-X

Roof, R. L., and Havens, M. D. (1992). Testosterone improves maze performance and induces development of a male hippocampus in females. Brain Res. 572, 310-313. doi: 10.1016/0006-8993(92)90491-Q

Roohbakhsh, A., Moghaddam, A. H., and Delfan, K. M. (2011). Anxiolytic-like effect of testosterone in male rats: GARA(C) receptors are not involved. Iran. J. Basic Med. Sci. 14, 376-382.

Ruigrok, A. N., Salimi-Khorshidi, G., Lai, M. C., Baron-Cohen, S., Lombardo, M. V., Tait, R. J., et al. (2014). A meta-analysis of sex differences in human brain structure. Neurosci. Biobehav. Rev. 39, 34-50. doi: 10.1016/j.neubiorev.2013.12.004

Sandstrom, N. J., Kim, J. H., and Wasserman, M. A. (2006). Testosterone modulates performance on a spatial working memory task in male rats. Horm. Behav. 50, 18-26. doi: 10.1016/j.yhbeh.2005.09.008

Sartorius, G., Spasevska, S., Idan, A., Turner, L., Forbes, E., Zamojska, A., et al. (2012). Serum testosterone, dihydrotestosterone and estradiol concentrations in older men self-reporting very good health: the healthy man study. Clin. Endocrinol. (Oxf). 77, 755-763. doi: 10.1111/j.1365-2265.2012. 04432.x

Schoning, S., Engelien, A., Kugel, H., Schafer, S., Schiffbauer, H., Zwitserlood, P., et al. (2007). Functional anatomy of visuo-spatial working memory during mental rotation is influenced by sex, menstrual cycle, and sex steroid hormones. Neuropsychologia 45, 3203-3214. doi: 10.1016/j.neuropsychologia.2007. 06.011

Schulz, K., and Korz, V. (2010). Hippocampal testosterone relates to reference memory performance and synaptic plasticity in male rats. Front. Behav. Neurosci. 4:187. doi: 10.3389/fnbeh.2010.00187

Seidman, S. N., Spatz, E., Rizzo, C., and Roose, S. P. (2001). Testosterone replacement therapy for hypogonadal men with major depressive disorder: a randomized, placebo-controlled clinical trial. J. Clin. Psychiatry 62, 406-412. doi: 10.4088/JCP.v62n0602

Shah, D. S., Prados, J., Gamble, J., De Lillo, C., and Gibson, C. L. (2013). Sex differences in spatial memory using serial and search tasks. Behav. Brain Res. 257, 90-99. doi: 10.1016/j.bbr.2013.09.027

Shors, T. J., and Miesegaes, G. (2002). Testosterone in utero and at birth dictates how stressful experience will affect learning in adulthood. Proc. Natl. Acad. Sci. U.S.A. 99, 13955-13960. doi: 10.1073/pnas.202199999

Silverman, I., Kastuk, D., Choi, J., and Phillips, K. (1999). Testosterone levels and spatial ability in men. Psychoneuroendocrinology 24, 813-822. doi: 10.1016/S0306-4530(99)00031-1

Spritzer, M. D., Daviau, E. D., Coneeny, M. K., Engelman, S. M., Prince, W. T., and Rodriguez-Wisdom, K. N. (2011). Effects of testosterone on spatial learning and memory in adult male rats. Horm. Behav. 59, 484-496. doi: 10.1016/j.yhbeh.2011.01.009

Spritzer, M. D., Fox, E. C., Larsen, G. D., Batson, C. G., Wagner, B. A., and Maher, J. (2013). Testosterone influences spatial strategy preferences among adult male rats. Horm. Behav. 63, 800-812. doi: 10.1016/j.yhbeh.2013.03.018

Spritzer, M. D., Gill, M., Weinberg, A., and Galea, L. A. (2008). Castration differentially affects spatial working and reference memory in male rats. Arch. Sex. Behav. 37, 19-29. doi: 10.1007/s10508-007-9264-2

Suarez-Jimenez, B., Gore, H. E., Hachey, J., King, H. M., and Lacreuse, A. (2013). Testosterone modulation of anxiety in gonadally-suppressed male rhesus monkeys: a role for gonadotropins? Pharmacol. Biochem. Behav. 104, 97-104. doi: 10.1016/j.pbb.2013.01.004

Tsai, M. J., and O'malley, B. W. (1994). Molecular mechanisms of action of steroid/thyroid receptor superfamily members. Annu. Rev. Biochem. 63, 451-486. doi: 10.1146/annurev.bi.63.070194.002315

Ubuka, T., Son, Y. L., Tobari, Y., Narihiro, M., Bentley, G. E., Kriegsfeld, L. J., et al. (2014). Central and direct regulation of testicular activity by gonadotropininhibitory hormone and its receptor. Front. Endocrinol. (Lausanne). 5:8. doi: 10.3389/fendo.2014.00008

Urbanski, H. F. (2011). Role of circadian neuroendocrine rhythms in the control of behavior and physiology. Neuroendocrinology 93, 211-222. doi: $10.1159 / 000327399$ 
Urbanski, H. F., Sorwell, K. G., Garyfallou, V. T., Garten, J., Weiss, A., Renner, L., et al. (2014). Androgen supplementation during aging: development of a physiologically appropriate protocol. Rejuvenation Res. 17, 150-153. doi: 10.1089/rej.2013.1518

Van Hemmen, J., Veltman, D. J., Hoekzema, E., Cohen-Kettenis, P. T., Dessens, A. B., and Bakker, J. (2014). Neural activation during mental rotation in complete androgen insensitivity syndrome: the influence of sex hormones and sex chromosomes. Cereb. Cortex. doi: 10.1093/cercor/bhu280. [Epub ahead of print].

Van Honk, J., Peper, J. S., and Schutter, D. (2005). Testosterone reduces unconscious fear but not consciously experienced anxiety: implications for the disorders of fear and anxiety. Biol. Psychiatry 58, 218-225. doi: 10.1016/j.biopsych.2005.04.003

Vuoksimaa, E., Kaprio, J., Eriksson, C. J. P., and Rose, R. J. (2012). Pubertal testosterone predicts mental rotation performance of young adult males. Psychoneuroendocrinology 37, 1791-1800. doi: 10.1016/j.psyneuen.2012. 03.013

Walf, A. A., and Frye, C. A. (2012). Gestational or acute restraint in adulthood reduces levels of 5alpha-reduced testosterone metabolites in the hippocampus and produces behavioral inhibition of adult male rats. Front. Cell. Neurosci. 6:40. doi: 10.3389/fncel.2012.00040

Weber, B., Lewicka, S., Deuschle, M., Colla, M., and Heuser, I. (2000). Testosterone, androstenedione and dihydrotestosterone concentrations are elevated in female patients with major depression. Psychoneuroendocrinology 25, 765-771. doi: 10.1016/S0306-4530(00)00023-8

Wolf, O. T., Preut, R., Hellhammer, D. H., Kudielka, B. M., Schurmeyer, T. H., and Kirschbaum, C. (2000). Testosterone and cognition in elderly men: a single testosterone injection blocks the practice effect in verbal fluency, but has no effect on spatial or verbal memory. Biol. Psychiatry 47, 650-654. doi: 10.1016/S0006-3223(99)00145-6
Yang, C. F. J., Hooven, C. K., Boynes, M., Gray, P. B., and Pope, H. G. (2007). Testosterone levels and mental rotation performance in Chinese men. Horm. Behav. 51, 373-378. doi: 10.1016/j.yhbeh.2006.12.005

Yonker, J. E., Eriksson, E., Nilsson, L. G., and Herlitz, A. (2006). Negative association of testosterone on spatial visualization in 35 to 80 year old men. Cortex 42 , 376-386. doi: 10.1016/S0010-9452(08)70364-2

Zarrour, F. A., Artz, S., Griffith, J., Sirbu, C., and Kommor, M. (2009). Testosterone and depression: systematic review and meta-analysis. J. Psychiatr. Pract. 15, 289-305. doi: 10.1097/01.pra.0000358315.88931.fc

Zuloaga, D. G., Jordan, C. L., and Breedlove, S. M. (2011). The organizational role of testicular hormones and the androgen receptor in anxiety-related behaviors and sensorimotor gating in rats. Endocrinology 152, 1572-1581. doi: 10.1210/en.2010-1016

Conflict of Interest Statement: The authors declare that the research was conducted in the absence of any commercial or financial relationships that could be construed as a potential conflict of interest.

Received: 25 August 2014; accepted: 12 January 2015; published online: 17 February 2015.

Citation: Celec P, Ostatníková D and Hodosy J (2015) On the effects of testosterone on brain behavioral functions. Front. Neurosci. 9:12. doi: 10.3389/fnins.2015.00012

This article was submitted to Neuroendocrine Science, a section of the journal Frontiers in Neuroscience.

Copyright (c) 2015 Celec, Ostatníková and Hodosy. This is an open-access article distributed under the terms of the Creative Commons Attribution License (CC BY). The use, distribution or reproduction in other forums is permitted, provided the original author(s) or licensor are credited and that the original publication in this journal is cited, in accordance with accepted academic practice. No use, distribution or reproduction is permitted which does not comply with these terms. 